\title{
ENVIRONMENTAL MANAGEMENT IN THE CONTEXT OF CORPORATE SUSTAINABILITY CONCEPT
}

\author{
doi: $\quad 10.2478 /$ czoto-2019-0045
}

Date of submission of the article to the Editor: $03 / 11 / 2018$

Date of acceptance of the article by the Editor: 18/12/2018

\author{
Petra Lesníková ${ }^{-}$orcid id: 0000-0001-9977-0811 \\ Jarmila Schmidtová ${ }^{2}$ - orcid id: 0000-0003-3985-9616 \\ ${ }^{1}$ Technical University in Zvolen, Slovakia, lesnikova@is.tuzvo.sk \\ ${ }^{2}$ Technical University in Zvolen, Slovakia
}

\begin{abstract}
The present age is marked by an unsustainable trends not only in the field of production but also in consumption, and concerns all levels of the community. At enterprise level, there is an effort to eliminate these negative trends by the application of several concepts in which environment and security are the essential parts. The paper focuses on environmental management as a significant part of the corporate sustainability concept and reports using of specific environmental tools to promote corporate sustainability. Apart from the tools, the paper also deals with motives that lead enterprises to focus on the environmental protection. The data were obtained through a questionnaire survey among Slovak manufacture enterprises. The focus of the research is transformed into several hypotheses. Several methods of inferential statistics (Interval estimate, Chi-square test, Kruskal-Wallis ANOVA, and Wilcoxon signed-rank test) were used to verify our hypotheses. In hypothesis testing we used .05 level of significance. Based on the descriptive statistics it is evident that $50 \%$ of the total number of enterprises $(\mathrm{N}=336)$ use at least one of the environmental management tools. Their using depends on the origin of capital. The results also indicate the individual benefits of focusing on environmental management and underline their importance to the business world.
\end{abstract}

Keywords: environmental management, performance, safety, tools, motives

\section{INTRODUCTION}

Many of the current researches address the issue of concepts such as corporate social responsibility (CSR) or corporate sustainability (CS). The essence of these concepts contributes to the fulfillment of sustainable development which refers to sustainable patterns of behavior at all levels in the sense of preserving future generations. The topic of sustainability began to explore in the early 70 s of the 20th century. At this time, it was gradually coming to the knowledge that any growth that is not controlled is unsustainable, in the area of limited resources (National Strategy of Sustainable Development SR, 2001). We can state that this trend has become even more intense in today's conditions. 
More detailed considerations on sustainability were brought by premise of the Meadows spouses' in the 1972 - The Limits to Growth. They reported that the cause of the ecological disaster in the next decade will be the depletion of non-renewable natural resources whereby the economic damages incurred will not be able to manage (Moldan, 2001). In this work the authors presented the results of their research and outlined possible aspects of the solution (Meadows et al., 1972). The importance of this issue underlines also the fact that world leaders are seeking to address the future directions through individual agendas. In 2015 were set 17 Sustainable Development Goals - 2030 Agenda for Sustainable Development. The main goal of this Agenda is to achieve a better and more sustainable future for all and the goals address the global challenges related to poverty, inequality, climate change, environmental protection, prosperity, and peace (the United Nations, 2018). Environmental protection and also safety are considered as significant parts of these challenges. Furthermore, environmental management as a component of the organization's overall management system promotes the protection of the environment and health from possible negative impacts of individual activities, products and services in interest of safety. In the paper we focus on the tools of environmental management and motives that drive enterprises to use them in their practice. For a deeper analysis of this issue we have set three hypotheses in relation to estimate of use particular tools, in relation to influence of capital structure on using these tools and also of importance individual motives.

\section{ESSENCE OF CORPORATE SUSTAINABILITY}

The general definition of sustainable development come from the Report of the UN's World commission on Environment and Development. According to this report "sustainable development is a development that meets the needs of today's generations without endangering our ability to meet the needs of future generations" (UNWCED, 1987). The challenges to which sustainable development refers are constantly transformed into concrete objectives in the individual documents: Agenda 21 (as a basic starting and conceptual document of sustainable development); EU Sustainable Development Strategy (with the aim of identifying and developing actions to enable the EU to achieve a continuous long-term improvement of every aspect of sustainable development); the Renewed Sustainable Development Strategy in 2006 (it sets out a single, coherent strategy of the EU leading to sustainable development); Europe 2020 strategy (it emphasizes smart, sustainable and inclusive growth) and already mentioned Agenda 2030 for Sustainable Development (Ministry of Environment of the SR; European Commission).

Corporate sustainability is seen as a concept of sustainable development at the corporate level with emphasis on performance in terms of the Triple Bottom Line. This approach advocates that the long-term success of an enterprise and its environment requires focus on all three dimensions of sustainability (economic, environmental, and social), rather than single, short term - only economic area of business (Amini and Bienstock, 2014). Elkington (2004) states the Triple Bottom Line presents a much more comprehensive approach that involves a wide range of stakeholders and areas of government policy, which, of course, reflects in the corporate environment.

In general this "sister of CSR" represents a challenge for the business world. At a closer view on this issue "sustainability standard can be defined as a set of voluntary predetermined rules, procedures and methods for systematically assessing, 
measuring, auditing, and/or communicating social and environmental behavior and / or performance of firms" (Reinecke, Manning and von Hagen, 2012, p. 793). An important fact remains that sustainable development and environmental protection will be a central of governance challenge - and even a market challenge - in the 21st century (Elkington 2004), which has been continuously persist. The research in the field of sustainability includes a system perspective, which gives attention to businessdriven failures in natural systems (Bansal and Song, 2017). This perspective is also reflected by the fact that sustainability should be an integral part of corporate strategy supported by control or performance measurement (Epstein, 2017).

\subsection{Environmental management as a part of corporate sustainability}

Management systems for ensuring quality, environmental and occupational safety play an important role in achieving of sustainable development goals. Moreover the stakeholders more and more expect to company to consider environmental and also social impacts of their decisions. In this way, enterprises are forced to include these areas into corporate goals and strategy (von Ahsen, 2013). In the broader context we understand environmental management as a management that allows to achieve and systematically control every environmental activity. Environmental management is not only a management of environment but it includes various activities as an environmental planning, environmental status evaluation, and environmental legislation and administration. Effort of environmental management is to minimize the negative impact of firm's products through their life cycle (Klassen and McLaughlin, 1996).

The United Nations Environment Programme encourages decision-makers (government and industry) to develop and adopt strategies and actions that are cleaner and safer. It means using of natural resources more efficiently way, to reduce pollution risks to human beings and the environment. Enterprises as a representatives of production and consumption field should focus on enhancing the resource efficiency, adopting cleaner and safer methods of production, and improving the design and life-cycle of products (Hillary, 2000). The International Organization for Standardization (ISO) recognized the need for standardization in the field of environmental management several tools as an environmental management systems and standards (ISO 14000), environmental reporting, eco-labeling, life cycle assessment and environmental indicators (European Environmental Agency, 1998). Also cleaner production is considered as a tool to reach sustainable development through the continuous application of an integrated preventative environmental strategy to processes, products and services (Gavrilescu, 2004). Environmental public procurement represents another voluntary tool which has a key role to play in the EU's efforts to become a more resource-efficient economy and it is therefore a strong stimulus for eco-innovation (European Commission).

\subsection{Motives leading to focus on environmental management}

The implementation and use of environmental management tools does not imply an immediate reduction of negative environmental impacts. One of the motives of application of tools is to get a higher environmental credit and a competitive advantage on both the national and international markets. Molina-Azorín et al. (2015) state that quality management and environmental management permit the improvement of competitive advantage in terms of both costs and differentiation. 
Cotrim et al. (2017) emphasis on motives as reduction in the consumption of materials, reduction in waste, reduction of greenhouses gas emissions. Among other motives or advantages to undertaking environmental management European Environmental Agency (1998) includes: cost savings (improve operational efficiency and performance), meeting supply chain requirements, improved public image or so on.

In this context, authors Campos et al. (2015) in their research demonstrate that a set of indicators of environmental performance continuously manage and improve the environmental and performance management of ISO 14001 certified companies in Brazil. Another research indicate that implementation of an environmental management system (ISO 140001 and EMAS) has a clear influence on environmental performance in the short and also in the long term (in the field of energy intensive industries) (Testa et al., 2014). Research of Dangellico et al. was oriented to the effect of different environmental management capabilities on a firm's market and image performance. The results indicate that these are positively affected variables.

\section{METODOLOGY OF RESEARCH}

In the paper we focused on environmental management which we consider as an important part of corporate sustainability concept and also as a significant challenge in the global framework. The aim of paper is evaluate the use of specific environmental tools and to study their use in connection with the origin of capital. Furthermore we payed attention to the motives leading to the use of environmental management tools. From our point of view, these aspects play an important role in meeting the goals of sustainable development as well as the safety of not only the environment but also the people's lives. In relation to this goals, we set following hypotheses:

- $\mathrm{H} 1$ : the enterprises use more than two environmental management tools.

- H2: enterprises with foreign capital use more environmental management tools than in the case of enterprises with domestic capital.

- H3: the use of tools by enterprises is mainly driven by improvement of operational efficiency and performance.

The primary data were obtained through a questionnaire survey. In the questionnaire, we mainly focused on:

- characteristic of enterprise (capital structure, size of enterprise),

- the use of environmental management tools,

- the motives leading to the use of these tools.

As we mention, center of our interest is the issue of environmental management tools used by Slovak enterprises. We obtained the database from Statistical Office of the Slovak republic and we focused on almost all size categories (small, medium-sized and large enterprises) with the exception of micro-enterprises. Our decision was due to the fact that the implementation and use of environmental management tools is relatively demanding and, in general, these companies are struggling with a lack of financial resources. Another characteristic was the field of industry. We selected the industries which have the greatest impact on the environment and it was only manufacturing oriented enterprises. The relationship of industry and its direction towards sustainable development is evident. It comes mainly from the improvement of production processes that are based on technologies and processes that use resources more efficiently while at the same time producing less waste. Industries 
include the introduction of technological innovation, their development, the cleaner production strategy, or the building of a comprehensive partnership (Agenda 21, 2001). Nemcová (2012) suggests that the most of the problems affecting the consumption of industrial products have an overall economic impact, the environmental impacts of industrial production are included in the industry's own competencies. The key to addressing these issues is technology and innovation.

The database consisted of 2,793 enterprises. We addressed 2,125 available enterprises. From this amount we obtained 501 answers. Subsequently, we excluded not correctly filled questionnaire. By this way our research sample consisted of 336 properly filled questionnaires.

Except ones all variables of our interest are categorical in nature - nominal or ordinal level of measurement. The variable number of tools is at ratio level of measurement Within the frame of the $\mathrm{H} 1$ we computed the interval estimate for the population proportion of enterprises which use more than two tools of environmental management. In connection with the $\mathrm{H} 2$ and $\mathrm{H} 3$ we used appropriate nonparametric methods of inductive statistics. Employed Chi-square and Maximum-Likelihood Chisquare tests are the most commonly used technique to test the existence of relationship between two categorical variables. In our research hypothesis $\mathrm{H} 2$ is important to know whether two such variables are statistically independent of one another or whether these variables, on the contrary, are statistically dependent - the probability of the occurrence of one is affected by the occurrence of the other. The data were cross-classified into a contingency table and the observed and expected frequencies were carried out. The Kruskal-Wallis ANOVA and Wilcoxon signed-rank test were employed to verify $\mathrm{H} 3$.

Data analyses were carried out using the statistical software STATISTICA 12. In hypothesis testing we used .05 level of significance.

\section{RESULTS}

Before the process of testing hypotheses, it is necessary to define a research sample by the means of descriptive statistics. In the sample were $53.27 \%$ small enterprises, $35.71 \%$ medium-sized enterprises, and $11.01 \%$ large enterprises. From the point of view of capital structure $62.50 \%$ of enterprises in the sample were with domestic capital and $37.50 \%$ enterprises with foreign capital. The following Table 1 more specifically characterizes the representation of enterprises in terms of twodimensional distribution - capital structure versus size of enterprise.

Table 1

Two-way distribution of the sample set (size versus capital)

\begin{tabular}{|l|l|l|l|}
\hline \multirow{2}{*}{ Small enterprises } & Domestic capital & Foreign capital & Total \\
\hline \multirow{2}{*}{ Medium-sized enterprises } & 142 & 37 & 179 \\
\cline { 2 - 4 } & $42.26 \%$ & $11.01 \%$ & $53.27 \%$ \\
\cline { 2 - 4 } & $16.96 \%$ & 63 & 120 \\
\hline \multirow{2}{*}{ Large enterprises } & 11 & $18.75 \%$ & $35.71 \%$ \\
\hline \multirow{2}{*}{ Total } & $3.27 \%$ & 26 & 37 \\
\hline & 210 & $7.74 \%$ & $11.01 \%$ \\
\cline { 2 - 4 } & $62.50 \%$ & 126 & 336 \\
\hline
\end{tabular}


Primary we analyzed the number of tools of environmental management by the means of descriptive statistics. According to this variable we portrayed distribution of all 336 enterprises to form of frequency table (Table 2). The point estimate of the population proportion of enterprises which use more than two tools is $17.56 \%$.

Table 2

Descriptive statistics of environmental management tools - frequency table

\begin{tabular}{|l|l|l|l|l|}
\hline $\begin{array}{l}\text { Number } \\
\text { of tools }\end{array}$ & $\begin{array}{l}\text { Absolute } \\
\text { frequencies }\end{array}$ & $\begin{array}{l}\text { Cumulative } \\
\text { absolute } \\
\text { frequencies }\end{array}$ & $\begin{array}{l}\text { Relative } \\
\text { frequencies } \\
\%\end{array}$ & $\begin{array}{l}\text { Cumulative relative } \\
\text { frequencies } \\
\%\end{array}$ \\
\hline 0 & 47 & 47 & 13.99 & 13.99 \\
\hline 1 & 168 & 215 & 50.00 & 63.99 \\
\hline 2 & 62 & 277 & 18.45 & 82.44 \\
\hline 3 & 27 & 304 & 8.04 & 90.48 \\
\hline 4 & 11 & 315 & 3.27 & 93.75 \\
\hline 5 & 13 & 328 & 3.87 & 97.62 \\
\hline 6 & 2 & 330 & 0.60 & 98.22 \\
\hline 7 & 3 & 333 & 0.89 & 99.11 \\
\hline 8 & 3 & 336 & 0.89 & 100 \\
\hline
\end{tabular}

Only one tool of environmental management use $50 \%$ of enterprises. The most used tool is clear production (45.24\%). It follows tools as the environmental management system - ISO 14001 (32.74\%), renewable resources (22.32\%). Among less used tools we include: environmentally/green public procurement (17.00\%), environmental reporting $(13.10 \%)$. In the range of $3-5 \%$ of using tools belongs EMAS, carbon footprint, lifecycle method, ecolabeling, or environmental accounting. With the increasing number of used tools, the number of enterprises using them is decreasing. In the first hypothesis $(\mathrm{H} 1)$ we assume that surveyed enterprises use more than two environmental management tools. We found 95\% confidence interval for the true population proportion by use of inferential statistics. More than $13.49 \%$ and less than $21.63 \%$ of enterprises in the population use more than two tools.

In the case of $\mathrm{H} 2$, at first, we transformed the variable the number of tools to fix categories from none tool to five and more tools. Two-dimensional distribution of all 336 enterprises according two traits - capital vs. number of tools is presented in Table 3.

Table 3

Contingency table: capital vs. number of tools - observed and expected (italics) frequencies

\begin{tabular}{|l|l|l|l|l|l|l|l|}
\hline $\begin{array}{l}\text { Capital/number of } \\
\text { tools }\end{array}$ & None & $\mathbf{1}$ tool & $\begin{array}{l}\mathbf{2} \\
\text { tools }\end{array}$ & $\begin{array}{l}\mathbf{3} \\
\text { tools }\end{array}$ & $\begin{array}{l}\mathbf{4} \\
\text { tools }\end{array}$ & $\begin{array}{l}\mathbf{5} \text { and } \\
\text { more }\end{array}$ & Total \\
\hline \multirow{2}{*}{ Domestic capital } & 36 & 116 & 34 & 14 & 5 & 5 & 210 \\
& 29.38 & 105.00 & 38.75 & 16.88 & 6.88 & 13.13 & \\
\hline \multirow{2}{*}{ Foreign capital } & 11 & 52 & 28 & 13 & 6 & 16 & 126 \\
& 17.63 & 63.00 & 23.25 & 10.13 & 4.13 & 7.88 & \\
\hline Total & 47 & 168 & 62 & 27 & 11 & 21 & 336 \\
\hline
\end{tabular}

Table 4 refers to the results of $\mathrm{H} 2$ testing. At the .05 level of significance there is sufficient evidence $(p=.000)$ to support the claim of $\mathrm{H} 2$. Significant relationship between the variables capital vs. number of tools exists in the population. 
Table 4

Results of Pearson and M-V Chi-square tests $(\alpha=.05)$

\begin{tabular}{|l|l|l|l|}
\hline Capital $\mathbf{x}$ tools & Value & Df & P-level \\
\hline Pearson Chi-Square & 24.69 & 5 & .00016 \\
\hline M-V Chi-Square & 24.56 & 5 & .00017 \\
\hline
\end{tabular}

Sequential graph of residual frequencies on the Fig. 2 illustrates that enterprises with prevailing domestic capital have a tendency to use none or one tool. The enterprises with foreign capital use more than two tools of environmental management.

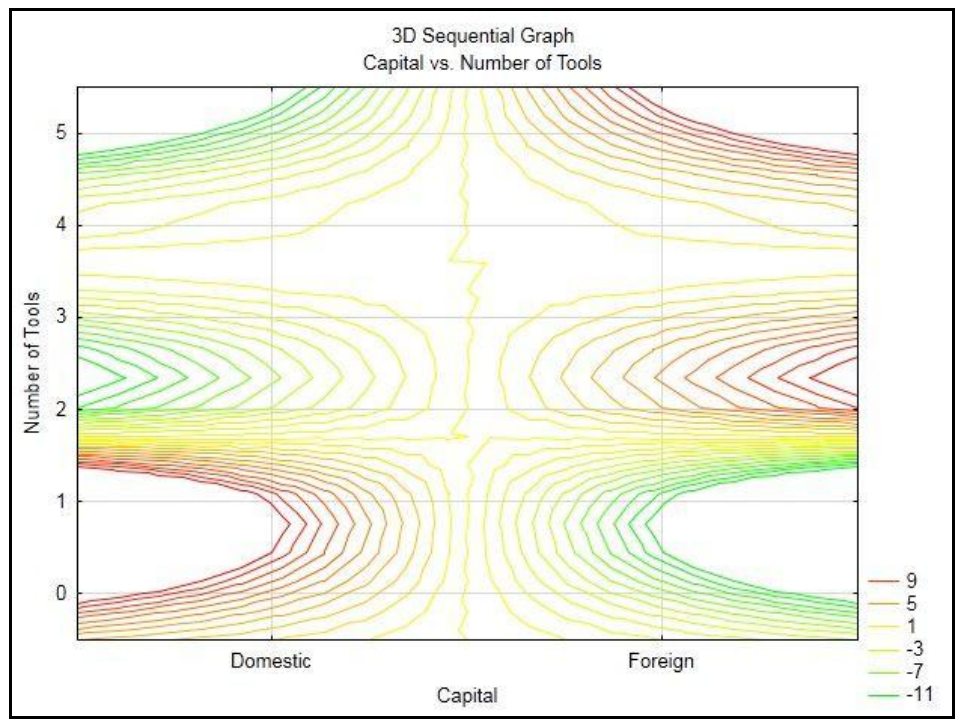

Fig. 1. Sequential graph of residual frequencies

We were also interested in the different motives leading to the application of environmental management tools by enterprises. The results of Kruskal-Wallis analysis of variance by ranks are displayed in Table 5 . There are highly significant $(p=.000)$ differences among the importance of the different motives that lead companies to implement the environmental management tools.

Table 5

Results of testing $\mathrm{H} 3$

\begin{tabular}{|l|l|l|l|}
\hline \multirow{2}{*}{ Individual motives } & \multicolumn{3}{|l|}{$\begin{array}{l}\text { Kruskal-Wallis ANOVA } \\
\mathbf{N}=\mathbf{2 0 1 6}, \mathbf{d f}=\mathbf{5}, \mathbf{N}=\mathbf{3 0 6 . 2 1 ,} \mathbf{p = . 0 0 0}\end{array}$} \\
\cline { 2 - 4 } & \multicolumn{1}{|c|}{$\mathbf{N}$} & \multicolumn{1}{|c|}{$\begin{array}{c}\text { Sum of } \\
\text { Ranks }\end{array}$} & \multicolumn{1}{|c|}{$\begin{array}{c}\text { Mean } \\
\text { Rank }\end{array}$} \\
\hline Improving reputation and image (a) & 336 & 335859 & 999.58 \\
\hline $\begin{array}{l}\text { Improving operational efficiency and performance } \\
\text { (b) }\end{array}$ & 336 & 263503 & 784.24 \\
\hline Environmental responsibility for own activities (c) & 336 & 353898 & 1053.27 \\
\hline Meeting customer requirements (d) & 336 & 256410 & 763.13 \\
\hline Distinction from competition (e) & 336 & 348821 & 1038.16 \\
\hline $\begin{array}{l}\text { Pressure from the public, government, non-profit } \\
\text { organizations (f) }\end{array}$ & 336 & 474645 & 1412.63 \\
\hline
\end{tabular}


Subsequently we tested differences between pairs of motives. Based on the results of Kruskal-Wallis ANOVA and Wilcoxon signed-rank test (Table 6), we can conclude that:

- Improving operational efficiency and performance (b) and meeting customer requirements (d) are not significantly different in their importance and they are the most motivating in using of environmental tools.

- Improving reputation and image (a), environmental responsibility for own activities (c) and distinction from competition (e) are less important with none significant differences between them.

- Pressure from the public, government, non-profit organizations (f) is significantly different in importance from the first two groups of motives and it is of minor importance to using of environmental tools.

Table 6

Results of reciprocal comparison of motives

\begin{tabular}{|l|l|l|l|l|l|}
\hline $\begin{array}{l}\text { Wilcoxon } \\
\text { signed-rank test }\end{array}$ & $(\mathbf{d})-(\mathbf{b})$ & $(\mathbf{b})-(\mathbf{a})$ & $(\mathbf{a})-(\mathbf{e})$ & $(\mathbf{e})-(\mathbf{c})$ & $(\mathbf{c})-(\mathbf{f})$ \\
\hline$Z$ & 0.793 & -5.526 & -0.967 & -0.327 & -9.360 \\
\hline p-level & .428 & .000 & .334 & .744 & .000 \\
\hline
\end{tabular}

In frame of $\mathrm{H} 3$ we can state that improvement of operational efficiency and performance is not only the most important motive which leading enterprises to use of environmental tools. The motive of meeting customer/supplier requirements is of the same importance $(p=.428)$. We consider this fact to be natural, as enterprises consider several motives to be equally important. The following Figure 2 clearly shows the results of analysis.

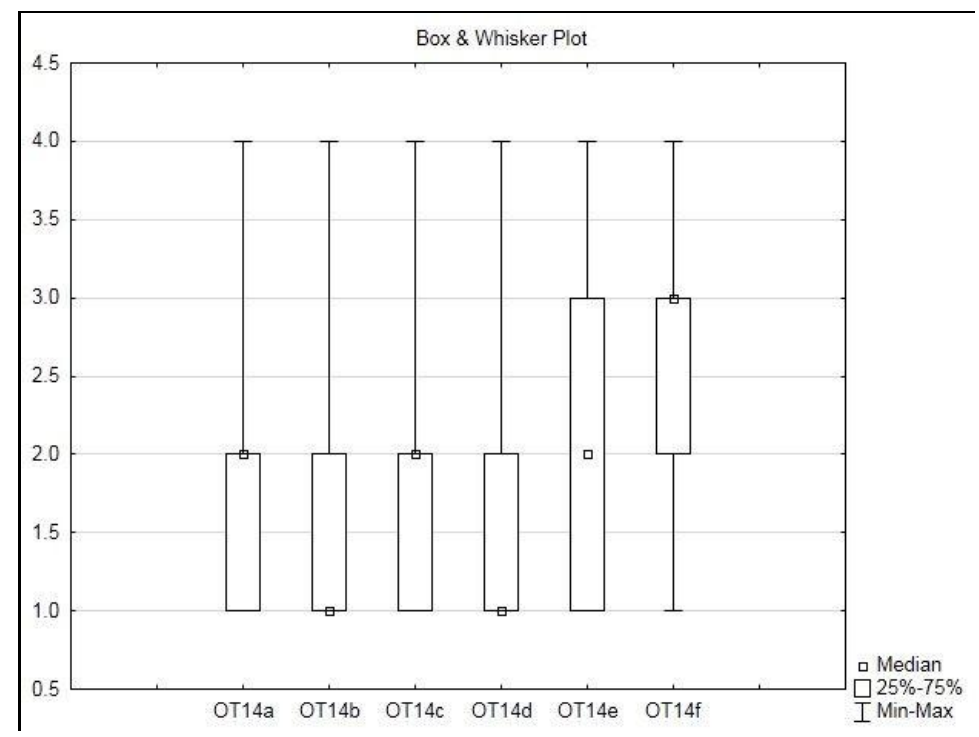

Fig. 2. View to the importance of individual motives

\section{CONCLUSION}

Nowadays many of enterprises try to implement individual tools to promote not only environmental protection but a wider sphere of community (e.g. concepts such as CS, or CSR). Environmental protection and many of environmental activities are related to 
these concepts. The paper is focused on environmental management as a significant part of the CS and reports using of specific environmental tools. The aim of paper was to evaluate the use of particular environmental tools and to study their use in connection with the origin of capital. Furthermore we payed attention to the motives leading to the use of environmental management tools (e.g. ISO 14001, clean production, environmental/green procurement, life cycle methods and so on). From our point of view, these aspects play an important role in meeting the goals of sustainable development as well as the safety of not only the environment but also the people's lives. To meet this goal we realized a questionnaire survey among Slovak manufacture enterprises. Depending on the aim of paper we formulated several hypotheses which were tested by statistic methods. Results showed that more than $13.49 \%$ and less than $21.63 \%$ of enterprises in the population use more than two tools. It is evident that $50 \%$ of the total number of enterprises $(\mathrm{N}=336)$ use at least one of the environmental management tools, but there are still many businesses that do not use the tools at all. Their using depends on the origin of capital which sufficient evidence $(p=.000)$ to support the claim of H2. It means that enterprises with domestic capital have a tendency to use none or one tool (lack of resources, less motivation, and so on). The enterprises with foreign capital use more than two tools of environmental management. The motive - improvement of operational efficiency and performance is not only the most important motive which leading enterprises to use of environmental tools but for enterprises this tools is very important. Enterprises could use the benchmarking which would allow them to compare with competitors or leading enterprises (a possible inspiration). Pressure from government or non-profit organizations had the least impact on used of tools, they might focus on more robust support for businesses (such as subsidies, enhancing enlightenment, or to provide assistance with tool applications). Limitations of our research are seen in the possibility of extending the sample of enterprises and also in the examining dependence between tools and environmental performance or between environmental performance and financial performance.

\section{ACKNOWLEDGEMENTS}

This paper is the partial result of the Ministry of Education of Slovak Republic grant project VEGA 1/0537/16-Methods and models of Strategic Business Performance Management and their comparison in companies and multinational corporations.

\section{REFERENCES}

Agenda 21 a trvalo udržatel'ný rozvoj: Deklarácia prijatá na konferencii OSN o životnom prostredí a rozvoji. Bratislava: Ministerstvo životného prostredia SR, $782 \mathrm{~s}$.

Amini, M. Bienstock, C.C., 2014. Corporate sustainability: an integrative definition and framework to evaluate corporate practice and guide academic research. Journal of Cleaner Production, 76, 12-19, DOI: 10.16/j.jclepro.2014.02.016.

Bansal, P., Song, H., 2017. Similar but not the same: differentiating corporate sustainability from corporate responsibility. Academy of Management Annals, 11(1), 105-149, DOI: 10.5465/annals.2015.0095.

Campos, L.M.S., Heizen, D.A.M., Verdinelli, M.A., Miguel, P.A.C., 2015. Environmental performance indicators: a study on ISO 14001 certified companies. Journal of Cleaner Production, 99, 286-296, DOI: 10.1016/j.jclepro.2015.03.019. 
Cotrim, S.L., Leal, G.C.L., Filho, D.A.M., 2017. Management tools as a support of cleaner production implementation: a case study in a food industry. International Journal of Services and Operations Management 28(4), 524-539, DOI: 10.1504/IJSOM.2017.087852.

Dangelico, R.M., Pontrandolfo, P., 2013. Being 'Green and Competitive": The Impact of Environmental Actions and Collaborations on Firm Performance. Business Strategy and the Environment, 24(6), 413-430, DOI:10.1002/bse.1828.

Elkington, J., 2004. Enter the Triple Bottom Line. The Triple Bottom Line: Does It All Add Up? Available online: http://www.johnelkington.com/archive/TBL-elkingtonchapter.pdf (accessed on 15.10.2018).

Epstein, M.J., 2017. Making Sustainability Work: Best Practices in Managing and Measuring Corporate Social, Environmental, and Economic Impacts. Routledge, New York, USA.

European Environmental Agency. 1998. Environmental Management Tools for SMEs: A Handbook, Denmark.

European Commission. EU Sustainable Development Strategy. Available online: http://ec.europa.eu/environment/sustainable-development/strategy/index_en.htm.

European Commission. Green Public Procurement. Available online: http://ec.europa.eu/environment/gpp/index_en.htm (accessed on 10.10.2018).

Gavrilescu, M., 2004. Cleaner production as a tool for sustainable development. Environmental Engineering and Management Journal, 3(1), 45-70.

Hillary, R., 2000. Small and Medium-Sized Enterprises and the Environment. Business Imperatives. First ed. Routledge, London, Great Britain.

Klassen, R.D., McLaughin, C.P., 1996. The Impact of Environmental Management on Firm Performance. Management Science, 42(8), 1199-1214, DOI:10.1287/mnsc.42.8.1199.

Meadows, D.H., Meadows, D.L., Randers, J., Behrens III, W.W., 1972. The Limits to Growth: A report to The Club of Rome. Available online: http://www.clubofrome.org/docs/limits.rtf (accessed on 20.10.2015).

Moldan, B., 2001. Ekologická dimenze udržitelného rozvoje. Praha, Karolinum, $102 \mathrm{~s}$.

Molina-Azorín, J.F., Tarí, J.J., Pereira-Moliner, J. López-Gamero, M.D., PertusaOrtega, E.M., 2015. The effects of quality and environmental management on competitive advantage: A mixed methods study in the hotel industry. Tourism Management, 50, 41-54, DOI: 10.1016/j.tourman.2015.01.008.

Národná stratégia trvalo udržatel'ného rozvoja. 2001. Available online: http://www.informatizacia.sk/starsie-/11147s\#Národná stratégia trvalo udržatel'ného rozvoja (accessed on 20.10.2015).

Nemcová, E., 2012. Udržatelný rozvoj verzus konkurencieschopnost' priemyslu EÚ. Bratislava: SAV Prognostické práce, 4(1), 51-69.

Reinecke, J., Manning, S., Von Hagen, O., 2012. The Emergence of a Standards Market: Multiplicity of Sustainability Standards in the Global Coffee Industry. Organization Studies, 33(5/6), 789-812.

Testa, F., Rizzi, F., Daddi, T., Gusmerotti, N.M., Frey, M., Iraldo, F., 2014. EMAS and ISO 14001: the differences in effectively improving environmental performance. Journal of Cleaner Production, 68, 165-173, DOI: 10.1016/j.jclepro.2013.12.061.

Transforming our world: the 2030. Agenda for Sustainable Development. United Nations. Available online: https://sustainabledevelopment.un.org/post2015 /transformingourworld (accessed on 10-10-2018). 
UNWCED, 1987. Towards Sustainable Development. In Our Common Future: Report of the World Commission on Environment and Development. Geneva, Switzerland.

von Ahsen, A., 2013. The Integration of Quality, Environmental and Health and Safety Management by Car Manufacturers - a Long-Term Empirical Study. Business Strategy and the Environment, 23(6), 395-416, DOI: 10.1002/bse.1791. 